\title{
Optimization of Parameters Affecting Anti-Icing Performance on Wing Leading Edge of Aircraft
}

\author{
Hayati Kadir Pazarlığlu ${ }^{1 *}$, Ahmet Ümit Tepe ${ }^{2}$, Kamil Arslan ${ }^{3}$ \\ ${ }^{1 *}$ Karabük University, Faculty of Engineering, Department of Mechanical Engineering, Karabük, Turkey, (ORCID: 0000-0002-9365-9431) \\ hayatikadirpazarlioglu@gmail.com \\ ${ }^{2}$ Sinop University, Department of Energy Systems Engineering, Sinop, Turkey, (ORCID: 0000-0001-7626-6348) \\ kamilarslan@karabuk.edu.tr \\ ${ }^{3}$ Karabük University, Faculty of Engineering, Department of Mechanical Engineering, Karabük, Turkey, (ORCID: 0000-0002-1216-6812) \\ autepe@sinop.edu.tr
}

(2nd International Conference on Applied Engineering and Natural Sciences ICAENS 2022, March 10-13, 2022)

(DOI: $10.31590 /$ ejosat.1062495)

ATIF/REFERENCE: Pazarlığlu, H. K., Tepe, A. Ü. \& Arslan, K. (2022). Optimization of Parameters Affecting Anti-Icing Performance on Wing Leading Edge of Aircraft. European Journal of Science and Technology, (34), 19-27.

\begin{abstract}
In this article, one of the hazardous trouble in-flight situations called ice accumulation on wing leading edge of aircraft has been numerically investigated. While the target surface is kept constant temperature at $T_{w}=263.15 \mathrm{~K}$, the inlet temperature is taken constant at $T_{i n}=473.15 \mathrm{~K}$ and it enters to the system with $\dot{m}=0.004 \mathrm{~kg} / \mathrm{s}$. The investigation starts with validation of numerical study utilizing airfoil type of NACA 0015 using constant piccolo tube dimensions, jet angle, distance among jets and distance between jet-to-target positions. The second and third stages are to analyze the anti-icing performance of changing positions of piccolo tube on $\mathrm{X}(4 \leq H / d \leq 8)$ and $\mathrm{Y}(-1.25 \leq L / d \leq 1.25)$ directions under different jet angles $\left(30^{\circ} \leq \alpha \leq 150^{\circ}\right)$. The fourth stage is to determine the optimum $H / d, L / d$, and $\alpha$ ratios to increase anti-icing performance with maximum convective heat transfer and minimum pressure drop condition. The optimization study has been done using Response Surface Methodology (RSM). Finally, while the best anti-icing performance proposed design is achieved using $\alpha=90^{\circ}, L / d=0.0$, and $H / d=4.0$, the optimization results show that the $\alpha, L / d$, and $H / d$ values should be $55.45^{\circ}$, 0.0 , and 4.0, respectively to achieve maximum heat transfer rate with minimum pressure drop value.
\end{abstract}

Keywords: Optimization, Anti-Icing, NACA 0015, Response Surface Methodology (RSM), CFD.

\section{Uçağın Kanat Hücum Kenarında Buzdan Arındırma Performansını Etkileyen Parameterelerin Optimizasyonu}

$\ddot{O} \mathbf{z}$

Bu çalışmada, uçuş esnasında tehlikeli durumlardan biri olan uçak kanat hücum kenarı üzerinde buz birikimi sayısal olarak araştırılmıştır. Hedef yüzey $T_{w}=263.15 \mathrm{~K}$ derecede sabit tutulurken, giriş sıcaklığı $T_{\text {in }}=473.15 \mathrm{~K}$ olarak $\dot{m}=0.004 \mathrm{~kg} / \mathrm{s}$. ile sisteme iletilmiştir. Araştırma NACA 0015 kullanarak sayısal çalışmanın sabit piccolo tüp ölçüleri, jet açısı ve jetler ve jet-hedef yüzey mesafeleri için doğrulama çalışması ile başlamıştır. İkinci ve üçüncü aşamada farklı jet açıları $\left(30^{\circ} \leq \alpha \leq 150^{\circ}\right)$ altında $X(4 \leq H / d \leq 8)$ ve $Y$ $(-1.25 \leq L / d \leq 1.25)$ yönünde değişen piccolo tüp pozisyonlarının buzdan arındırma performansını incelemektir. Dördüncü aşama buzdan arındırma sisteminin performansını maksimum taşınım ısı transfer ve minimum basınç azalımı durumu ile artırmak için optimum $H / d$, $L / d$ ve $\alpha$ oranlarını belirlemektir. Optimizasyon çalışması Yüzey Cevap Metodolojisi kullanılarak yapılmıştır. Sonuç olarak, teklif edilen tasarımda en yüksek buzdan arındırma performansı $\alpha=90^{\circ}, L / d=0.0$ ve $H / d=4.0$ kullanılarak başarılırken, optimizasyon çalışmaları maksimum 1sı transfer oranı ve minimum basınç düşüşü değerini başarmak için $\alpha, L / d$ ve $H / d$ değerlerinin sirasıyla $55.45^{\circ}, 0.0$ ve 4.0 olması gerektiğimi göstermiştir.

Anahtar Kelimeler: Optimizasyon, Buzdan Arındırma, NACA 0015, Yüzey Cevap Metodolojisi, HAD

"Corresponding Author: hayatikadirpazarlioglu@gmail.com 


\section{Introduction}

With the developing operating temperature of newly designed devices, the more cooling or heating performance is needed more than conventional devices. For this purpose, the active and passive heat transfer techniques have been taken into consideration to achieve more convective heat transfer rate. To obtain higher heat removal on the surfaces, the jet impingement method, which is one of the most important active heat transfer techniques, is often utilized in several industrial areas such as electronic equipment cooling [1], micro or nano-scale cooling [2], increase of effect of nanofluid's cooling performance [3], gas turbine blade cooling [4], and solar air heater's absorber surface cooling [5]. On the other hand, the use of air jet impingement method is usually preferred for anti-icing application of aircraft [6]. Besides, the anti-icing application can be applied for wind turbine's blade due to high velocity fluctuations on the leading edge of it [7]. The ice shape, mass, droplet shape, and prediction of accumulation of it using numerical methods are the most important parameters in flight industries to minimize in-flight accidents [8]. Özgen and Canıbek [9] studied to determine ice shape and mass on NACA profile using extended Messinger model. The ice shape has been investigated using single and twoelement configurations. While lower liquid water content with low temperature leads to occurring rime ice shape, higher liquid water content with higher temperature causes to creating glaze ice forms. It is also reported that two-element configuration has presented well prediction in comparison with single-layer configuration. Myers [10] investigated ice accumulation on the surface impacting supercooled droplets. Single layer theoretical model is used to predict icing situation. The extended Messinger model has been used to predict ice growth. It is reported that the extended Messinger model showed better prediction than convectional Messinger model. Mingione and Brandi [11] presented performance of Italian Icing Computational Environment Code $\left(\mathrm{I}^{2} \mathrm{CE}\right)$ coded by CIRA. The code is tried on single and multi-element wings. It is determined that the $\mathrm{I}^{2} \mathrm{CE}$ developed by Italian researchers can predict ice growth. Myers et al. [12] performed a theoretical study to predict ice growth occurred due to impact of droplet trajectories to the surface. While the rime ice accumulations are solved using mass balance, the glaze ice accumulations are determined using mass and energy balances. To predict ice growth, ICECREMO code has been developed. The program presented very well approximation for ice growth. Cebeci et al. [13] discussed ice shapes, accumulations and their effects on the aircraft's wing in terms of lift and drag coefficients. The interactive boundary-layer method has been developed by Cebeci to predict very well ice accumulation happened in multiple stagnation points. When the developed code compared to LEWICE code used previously in ice prediction application, the Cebeci's code can estimate ice shape and performance of iced aircraft wing well than LEWICE code. Ayan and Özgen [14] developed a hand-made code to predict solid and mixed phase icing situation occurred on the aircraft wing in-flight condition. The numerical code developed by researchers is checked with experimental data for both solid and mixed conditions. It is conducted that the code developed can estimate icing situation satisfactorily.

In the present study, the ice accumulation on the NACA 0015 at $263.15 \mathrm{~K}\left(-10^{\circ} \mathrm{C}\right)$ has been minimized using different configurations. The findings are elucidated in terms of average Nusselt number, local Nusselt number, and pressure drop associated with anti-icing performance of newly proposed design. Also, the flow characteristics taken place in NACA 0015 have been assessed using different contours.

\section{Material and Method}

The model is constructed two different sections: curved surface of NACA 0015 and piccolo tube. The configurations of NACA 0015 can be seen in Fig. 1. The length of NACA 0015 on $\mathrm{X}$ direction is kept as $300 \mathrm{~mm}$. The maximum height of NACA 0015 on $\mathrm{Y}$ direction is applied as $150 \mathrm{~mm}$. The piccolo tube position between target surface and it on $\mathrm{X}$ direction has been changed with dimensionless parameters $(4 \leq H / d \leq 8)$. Then, the piccolo tube position on $\mathrm{Y}$ direction has been arranged with dimensionless parameters $(-1.25 \leq L / d \leq 1.25)$. Also, the circular jet has been designed with different jet angles $\left(30^{\circ} \leq \alpha \leq 150^{\circ}\right)$. The jet diameter is kept as $4 \mathrm{~mm}$. The outlet hole diameter is considered as $3 \mathrm{~mm}$. The piccolo tube diameter $\left(D_{\text {piccolo }}\right)$ is selected as $36 \mathrm{~mm}$. The mass flux rate at inlet section is taken constant as $\dot{m}=0.004$ $\mathrm{kg} / \mathrm{s}$. The fluid domain and boundary conditions can be seen in Fig. 3a.

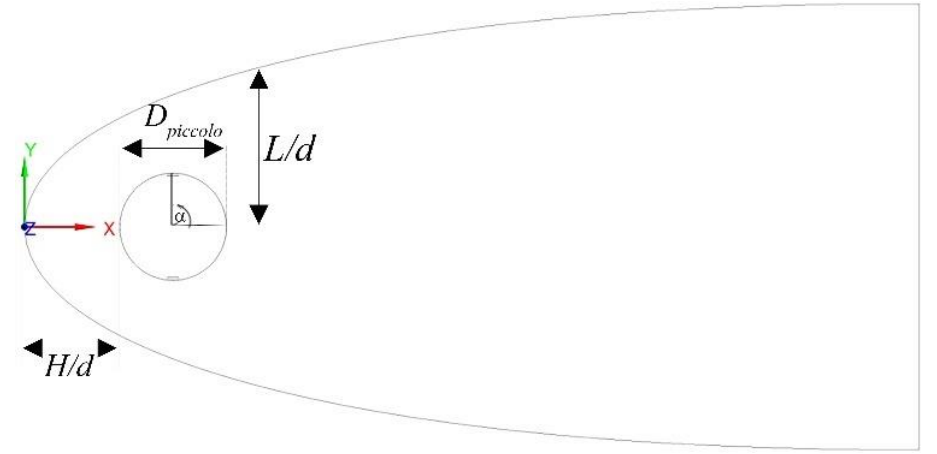

Fig. 1. Fundamental parameters of present study.

The computational model has been solved using ANSYS Fluent 2020R2 software. The RANS (Reynolds-Averaged Navier-Stokes) equations has been solved iteratively. The governing equations used in these calculations are showed as following:

Continuity equation [15]:

$$
\frac{\partial \rho}{\partial t}+\frac{\partial\left(\rho u_{i}\right)}{d x}=0
$$

Momentum equation [15]:

$$
\begin{aligned}
& \frac{\partial\left(\rho u_{i}\right)}{\partial t}+\frac{\partial\left(\rho u_{i} u_{j}\right)}{\partial x_{j}}=-\frac{\partial P}{\partial x_{i}}+\frac{\partial}{\partial x_{j}} \\
& {\left[\mu\left(\frac{\partial u_{i}}{\partial u_{j}}+\frac{\partial u_{j}}{\partial x_{i}}-\frac{2}{3} \delta_{i j} \frac{\partial u_{i}}{\partial x_{j}}\right)\right]+i \frac{\partial}{\partial x_{j}}\left(-\rho \overline{u_{i}^{\prime} u_{j}^{\prime}}\right)}
\end{aligned}
$$

Energy equation [15]:

$$
\begin{aligned}
& \frac{\partial}{\partial t}(\rho E)+\frac{\partial}{\partial x_{i}}\left[u_{i}(\rho E+\operatorname{Pr})\right]= \\
& \frac{\partial}{\partial t}\left[\left(k+\frac{C \mu_{i}}{\operatorname{Pr}_{t}}\right)\right] \frac{\partial T}{\partial x_{j}}+\mu_{i}\left(\tau_{i j}\right)_{e f f}
\end{aligned}
$$


Then, to explain anti-icing performance of proposed design, the dimensionless numbers are utilized in this study as below:

Reynolds number and mass flux equations [15]:

$\operatorname{Re}=\frac{\rho V_{a v g} D_{h}}{\mu}$

where, $\rho$ defines density of working fluid $\left[\mathrm{kg} / \mathrm{m}^{3}\right], \mathrm{V}_{\text {avg. defines }}$ average velocity of working fluid $[\mathrm{m} / \mathrm{s}], D_{h}$ explains hydraulic diameter of circular jet hole $[\mathrm{m}], \mu$ expresses dynamic viscosity value of working fluid $[\mathrm{Pa} . \mathrm{s}]$.

Nusselt number equation [15]:

$\overline{N u}=\frac{\bar{h} D_{h}}{k}$

where, $\bar{h}$ defines average convection heat transfer coefficient $\left[\mathrm{W} / \mathrm{m}^{2} \mathrm{~K}\right], k$ is the thermal conductivity of working fluid $[\mathrm{W} / \mathrm{mK}]$.

The turbulent intensity is defined as follow [16]:

$I=0.16 \operatorname{Re}^{(-1 / 8)}$

Also, the symmetric NACA profile can be designed in 2D design as follow [17]:

$$
y_{t}=5 t\left[\begin{array}{l}
0.2969 \sqrt{x}-0.1260 x-0.3516 x^{2} \\
+0.2843 x^{3}-0.1015 x^{4}
\end{array}\right]
$$

where, $t$ describes height of NACA profile $[m], x$ defines location of $\mathrm{X}$ direction $[\mathrm{m}]$.

Once the 2D model of NACA 0015 is created in Ansys Design modeler, the model has been converted to the 3D model. This model can be seen in Fig. 3 a.

The working fluid is blowed to the system from piccolo tube at $T_{\text {inlet }}=473.15 \mathrm{~K}$. The constant surface temperature is also addicted to the target surface at $T_{w}=263.15 \mathrm{~K}$. No-slip boundary conditions are applied all the domain wall, but adiabatic boundary conditions are also applied for piccolo tube, periodic walls, and rear wall of domain. The pressure outlet condition is applied for outlet section. The mass flux inlet boundary condition is also defined at inlet as $\dot{m}=0.004 \mathrm{~kg} / \mathrm{s}$. The pressure-velocity scheme is selected as COUPLED method. Then the equations are updated as second-order upwind scheme. The residual values are reached until $10^{-4}$ as a convergency criteria. The thermo-physical properties of working fluid can be seen in Table 1 .

Table 1. Thermo-physical properties of working fluid at $T_{\text {inlet }}=473.15 \mathrm{~K}$.

\begin{tabular}{lllll}
\hline Fluid & $\begin{array}{l}\text { Density } \\
{\left[\mathrm{kg} / \mathrm{m}^{3}\right]}\end{array}$ & $\begin{array}{l}\text { Dynamic } \\
\text { Viscosity } \\
{[P a . s]}\end{array}$ & $\begin{array}{l}\text { Specific } \\
\text { Heat } \\
{[\mathrm{J} / \mathrm{kgK}]}\end{array}$ & $\begin{array}{l}\text { Thermal } \\
\text { Conductivity } \\
\end{array}$ \\
\hline Air & 0.7459 & $2.58 e-05$ & 1023 & 0.03779 \\
\hline
\end{tabular}

On the other hand, the mesh structure is the most important issue on finite volume method application. Nevertheless, the denser mesh does not good every time so the denser mesh type should be applied to the important zone in the analyses. Besides, doing denser mesh structure in important zones apart from other zones provide less mesh element number than doing denser mesh type everywhere. For this way, the computational time can be decreased. To decide feasible mesh structure and mesh element number, several numerical analyses have been done.

As seen from Table 2, there is not any considerable changing between M3 and M4 in terms of average Nusselt number value. The $y^{+}$value is the most important value in numerical calculations to well approximate boundaries of fluid domain. In this study, since the SST $k-\omega$ with low-Re correction wall model has been used, the $y^{+}$value should be lower than 1 . For this purpose, the value is kept lower than 1 . Therefore, the $M 3$ mesh type has been chosen for optimum mesh number.

Table 2. Mesh independency study.

\begin{tabular}{ccccc}
\hline & M1 & M2 & M3 & M4 \\
\hline $\begin{array}{c}\text { Elements } \\
\text { No. }\end{array}$ & 962584 & 1521455 & 4121777 & 5182744 \\
\hline $\boldsymbol{N u}$ & 178.27 & 210.24 & 262.45 & 270.55 \\
\hline $\boldsymbol{y}^{+}$ & 1.02 & 0.98 & 0.87 & 0.87 \\
\hline
\end{tabular}

As can be examined in Fig. 3b, the denser mesh type is conducted to jet flow way, jet impingement zone, and outlet section of NACA 0015.

Once determining the optimum mesh structure, the optimum turbulence model should be spotted to achieve better validation and findings. To determine optimum situation and validation parameters, experimental study of Yang et al. [18] is created on ANSYS Fluent. In their study, the three circular jet holes placed on piccolo tube has been used and the inlet temperature is kept as $300 \mathrm{~K}$. The constant and uniform heat flux $\left(1500 \mathrm{~W} / \mathrm{m}^{2}\right)$ is applied to the NACA 0015 's surface. The Reynolds number is chosen as 47367. The piccolo tube position to the target surface $(H / d)$ is selected as 10 and the jet-to-jet distance $(S / d)$ is chosen as 25 . In this section of the study, the five different turbulence model, which is the most preferred in the impinging jets and aerospace application, are tried to determine optimum turbulence model. While the standard and realizable $k-\varepsilon$ models present the hugest error rate compared to experimental data, the RNG $k-\varepsilon$ and Spalart-Allmaras turbulence models show better approximation in comparison with experimental data. Nonetheless, the SST $k$ - $\omega$ model consists of experimental data of Yang et al. (see Fig. 2.) The first and third jet is approximate a bit far, but middle jet catches it very well. The turbulence formulation of SST $k$ - $\omega$ can be seen in Menter's study [19].

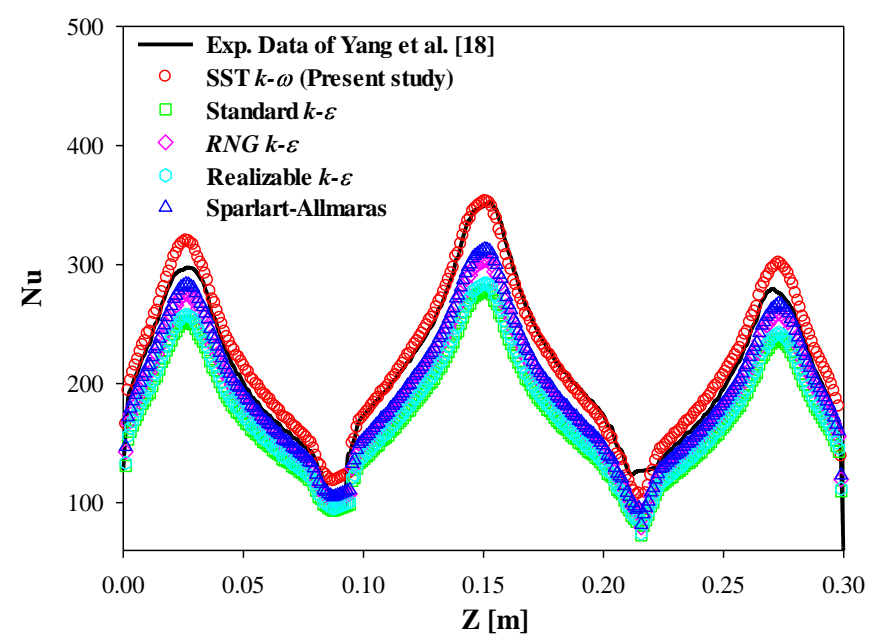

Fig. 2. Literature validation and selection of turbulence model. 


\section{Avrupa Bilim ve Teknoloji Dergisi}
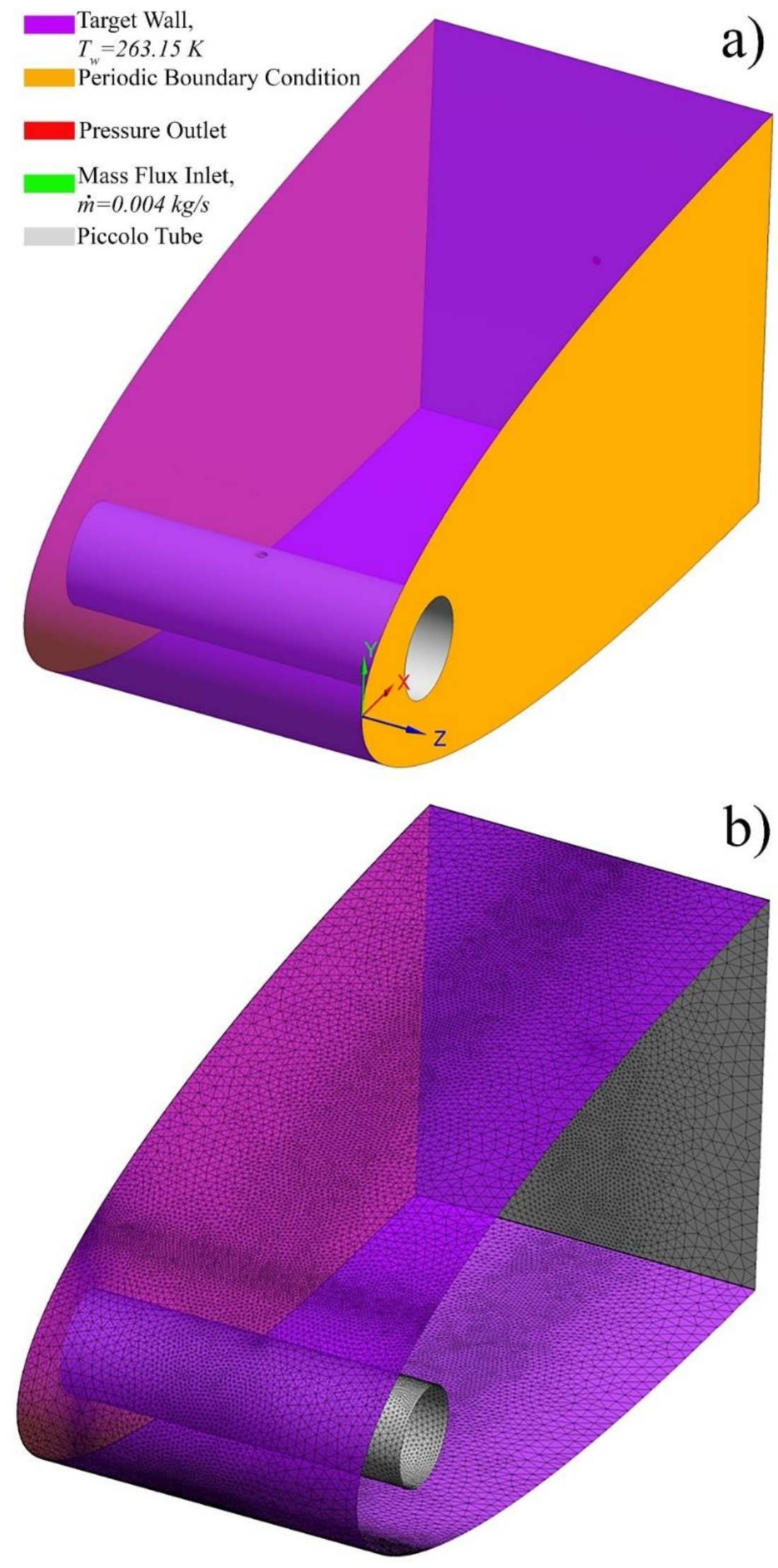

Fig. 3. NACA 0015 a) fluid domain with boundary conditions, b) mesh structure. 


\subsection{Response Surface Methodology (RSM)}

In the engineering or industrial problems, finding of the best values does not sufficient results to decide the finding can be used in these problems. To handle this problem, the optimum parameters should be found to arrange better budget plan. In the literature, the $R S M$ is generally used to determine optimum parameters investigated. Using $R S M$ model provides multi-layer optimization compared to other optimization method. The easiest model used in RSM optimization can be presented as follow:

$y=\beta_{0}+\sum_{i}^{k} \beta_{i} x_{i}+\varepsilon$

$y=\beta_{0}+\sum_{i}^{k} \beta_{i} x_{i}+\sum_{i=1}^{k} \sum_{j \geq i}^{k} \beta_{i j} x_{i} x_{j}+\varepsilon$

To understand quality of optimization and experiment values, the $R^{2}, A d j . R^{2}$, and Pred. $R^{2}$ is the essential values. The $R^{2}$ value generally should be higher than $95 \%$ but the finding of it higher than $90 \%$ can be acceptable condition as said in the literature.

$$
R^{2}=1-\left[\frac{S S_{\text {residual }}}{S S_{\text {residual }}+S S_{\bmod e l}}\right]
$$

Adj. $R^{2}=1-\left[\left(\frac{S S_{\text {residual }}}{d f_{\text {residual }}}\right) /\left(\frac{S S_{\text {residual }}+S S_{\bmod e l}}{d f_{\text {residual }}+d f_{\bmod e l}}\right)\right]$

$\operatorname{Pr} e d \cdot R^{2}=1-\left[\frac{P R E S S}{S S_{\text {residual }}+S S_{\text {model }}}\right]$

Using of Analysis of Variance (ANOVA) shows the contribution of input parameters in terms of statistically. In this table, while the contribution ratio shows to effect of input parameters to understand which input parameter mor effective, the p-value presents again effective parameter statically. When the $\mathrm{p}$-value lower than 0.005 for a parameter, it means that the parameters is the effective parameter statistically.

\section{Results and Discussions}

\subsection{Anti-Icing Performance}

The effect of changing of piccolo tube parameters is elucidated in terms of average Nusselt number value. The average Nusselt number values are presented in the range of $H / d$ ratios. As seen in Fig. $4(a, b, c)$, increase in average Nusselt number defines the enhancement in anti-icing performance of parameter analysed.

It is noted that the increase in $H / d$ ratio leads to decrease in average Nusselt number value and so anti-icing performance of design. Therefore, the maximum anti-icing performance obtained using $H / d=4$. Then, doing a nonconcentric design for piccolo tube leads to decrease in average Nusselt number value. Hence, the changing of $L / d$ ratios cause to decrease in that value. So, the maximum enhancement in anti-icing performance is obtained using $L / d=0$ called concentric design. Also, the design of different $\alpha$ shows the most effective changing in average Nusselt number. As seen, the increase in average Nusselt number is achieved until $\alpha=90^{\circ}$. Once the use of $120^{\circ}$ and $150^{\circ}$ cause decrease effect for every $H / d$ and $L / d$ ratios. So, the maximum average Nusselt number value is gotten using $\alpha=90^{\circ}$.
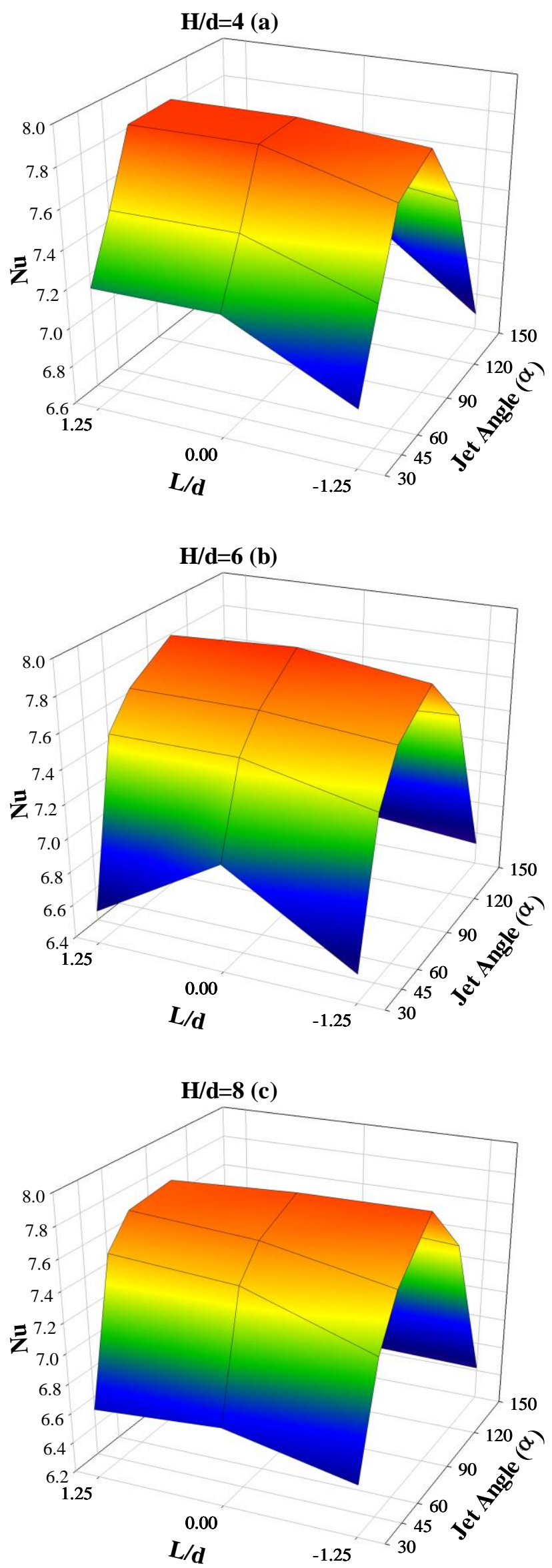

Fig. 4. Average Nusselt number value under different L/d and $\alpha$ values for a) $H / d=4$, b) $H / d=6$, c) $H / d=8$. 
The local Nusselt number distribution on chord-wise direction of NACA 0015 is presented in Fig. 5. The maximum and minimum local Nusselt number distribution is obtained using $90^{\circ}$ and $150^{\circ}$, respectively. The use of $\alpha$ between $30^{\circ}$ and $90^{\circ}$ leads to increase in local heat transfer significantly but after $90^{\circ}$, the local Nusselt number value decreasing dramatically.

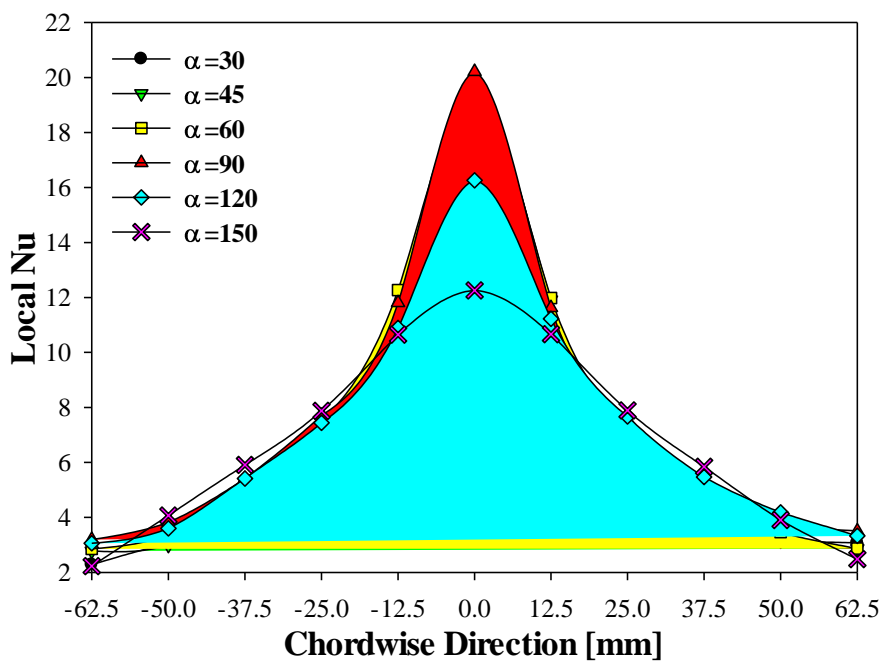

Fig. 5. Local Nusselt number distribution on chord-wise direction of NACA 0015 under different jet angle for $H / d=4$ and $L / d=0$.

The pressure drop value is the most essential in an investigation due to effecting cost and design parameters drastically. It is realised that the closer piccolo tube position to target surface leads to increase in pressure drop value due to more impact power to the surface. So, the higher $H / d$ ratio causes to decrease in pressure drop value. By the way, the $L / d$ ratio does not affect to pressure drop value significantly. Generally, the use of $L / d$ as -1.25 or 1.25 leads to more pressure drop due to closer to the upper or lower target surface of NACA 0015 compared to concentric one. The concentric position of piccolo tube presents good performance in terms of pressure drop value.

The pressure drop value is affected to much both $L / d$ and $\alpha$. If it is spoken for $L / d=0$ and $H / d=4$, the increase of $\alpha$ leads to increase pressure drop. So, the highest pressure drop value is obtained using $150^{\circ}$. However, it is examined that increase in $H / d$ ratio changes the results in terms of $L / d$ ratio (Fig. 6).

The effect of $\alpha$ with the use of $H / d=4$ and $L / d=0$ is presented in Fig. 7 in terms of temperature distribution in NACA 0015. The melting of icing accumulation on the surface is significantly enhanced until $90^{\circ}$ but there is going on ice accumulation on the rear surface of NACA 0015 called run-back effect. With the use of $120^{\circ}$ and $150^{\circ}$, the ice accumulation on the rear surface of NACA 0015 is hugely decreased but the icing on the wing leading edge is still going on due to jet positions. For this reason, the most effective one in terms of anti-icing application can be selected as $90^{\circ}$ due to more icing defrosting performance both wing leading edge and rear surface of NACA 0015.
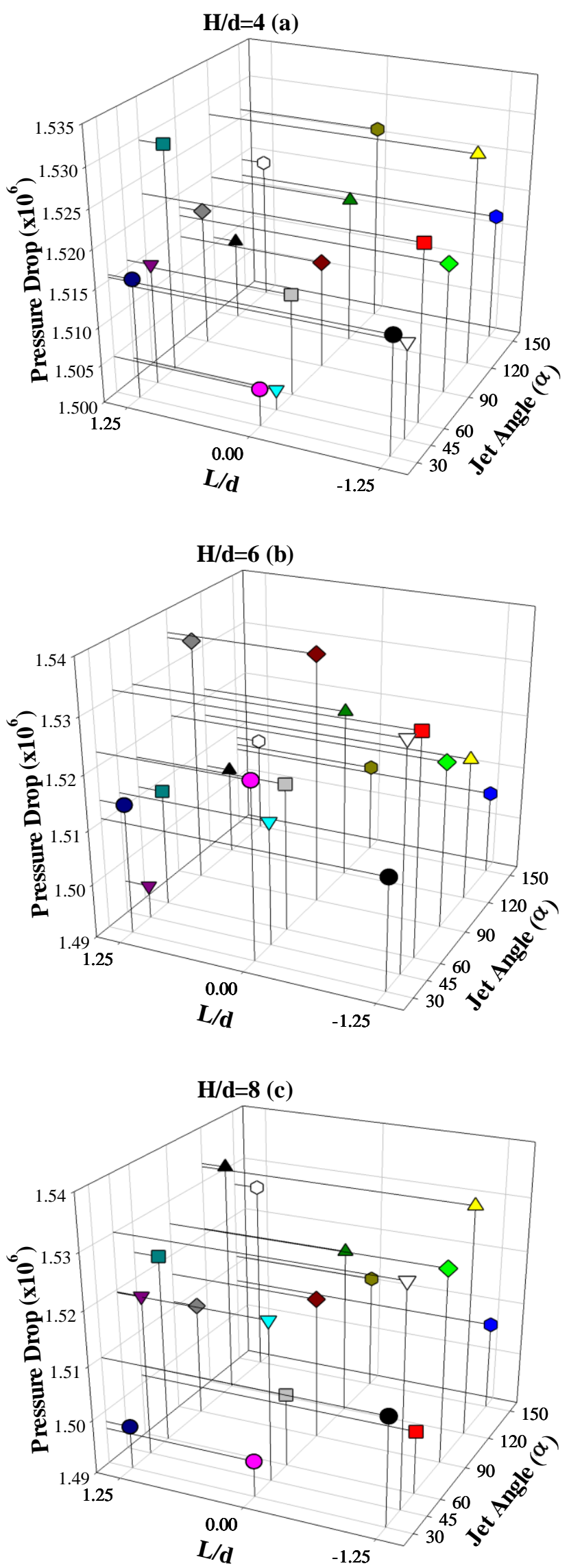

Fig. 6. Pressure drop value under different $L / d$ and $\alpha$ values for a) $H / d=4$, b) $H / d=6$, c) $H / d=8$. 

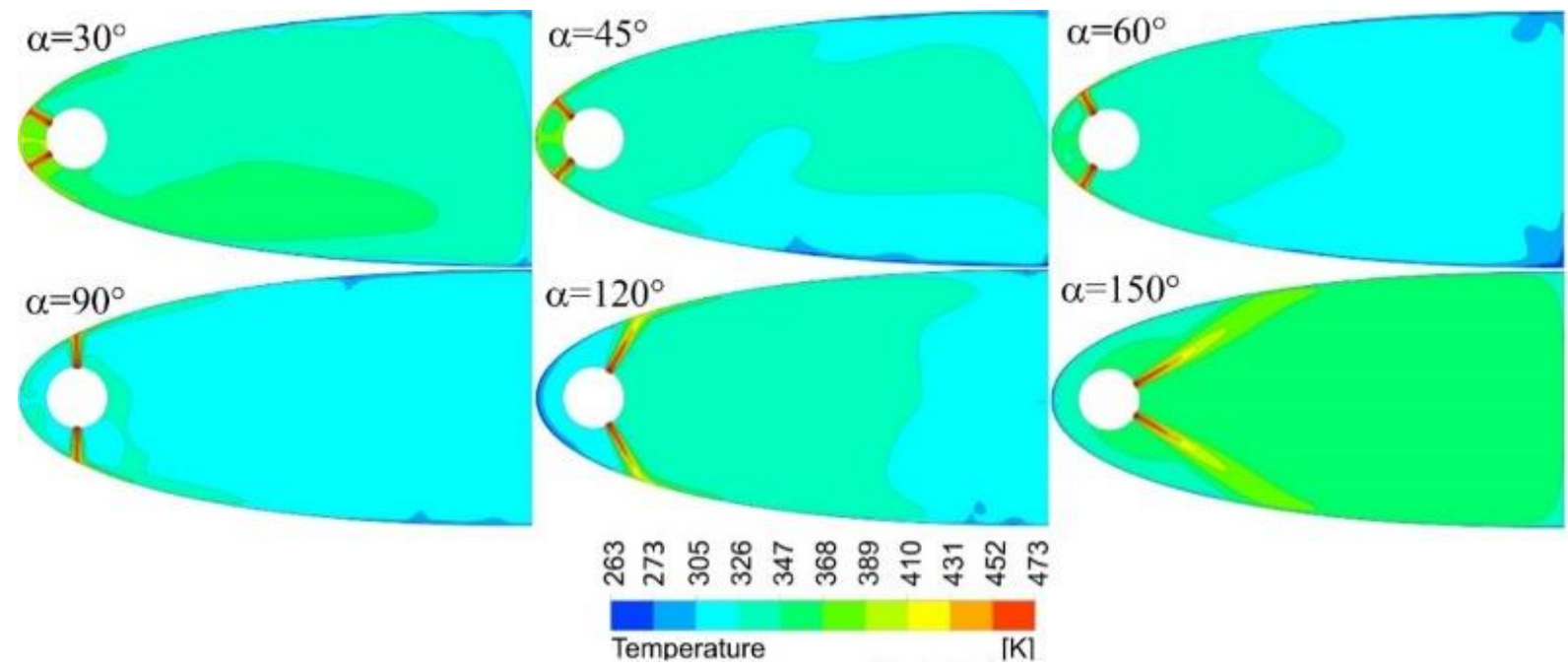

Fig. 7. Temperature distribution in NACA 0015 for different jet angles $(\alpha)$ at $L / d=0$ and $H / d=4$.

\subsection{Optimization Results}

In this section of the study, the optimum $H / d, L / d$ and $\alpha$ values is determined for circular jet hole. The determine optimum values for anti-icing application provides more effective use in terms of convective heat transfer.

The $\mathrm{R}^{2}$ value can be seen in Table 3 both average Nusselt number and pressure drop value. As seen from table, $\mathrm{R}^{2}$ values are higher than $95 \%$, so the optimization is well planned, and the analyses is well done.

The ANOVA values can be seen in Table 5 both average Nusselt number and pressure drop value. While the highest contribution ratio in terms of average Nusselt number is obtained as jet angle by $5.13 \%$, the highest contribution ratio in terms of Pressure drop is seen as jet angle by $89.32 \%$. Also, while the lowest p-value is gotten as 0.007 in terms of average Nusselt number and it means that the jet angle is not effective parameter statistically in average Nusselt number, the lowest p-value is obtained as 0 in terms of Pressure drop and it means that the jet angle is effective parameter statistically in pressure drop.

Table 3. Model summary of average Nusselt number and pressure drop $(\triangle P)$ values in $R S M$.

\section{Model Summary}

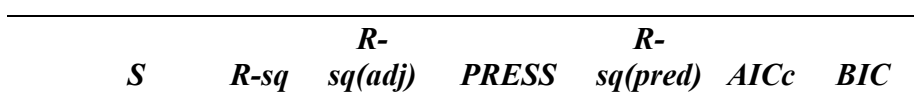

\begin{tabular}{llllllll}
\hline$N u$ & 0.147586 & $96.12 \%$ & $91.75 \%$ & 0.878210 & $80.43 \%$ & 33.60 & -0.60
\end{tabular}

\section{$\begin{array}{llllllll}2595.85 & 96.49 \% & 92.55 \% & 381750016 & 75.16 \% & 385.51 & 351.30\end{array}$}

Finally, the optimization results are presented in Fig. 8. As seen from figure, the optimum $\alpha, L / d$ and $H / d$ ratios is obtained as $55.45,0.0,4.0$, respectively. The desirability value is gotten as $D=0.7556$.

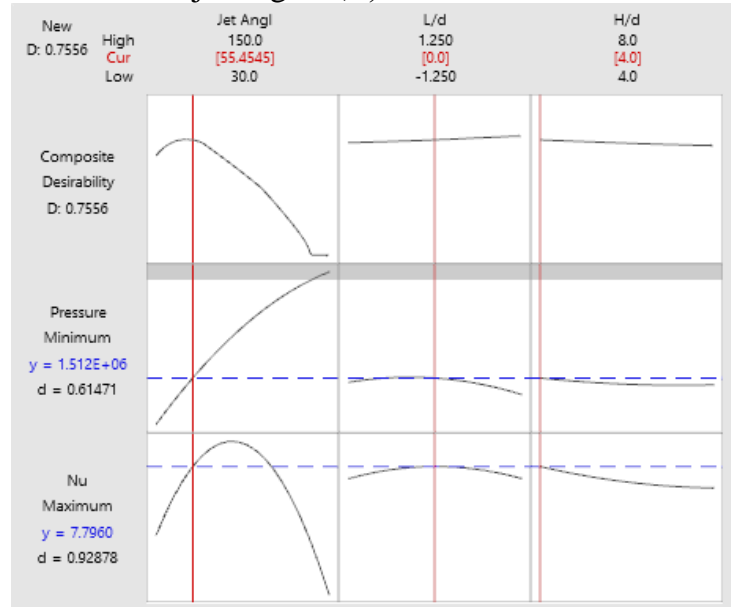

Fig. 8. Optimization chart of circular jet hole about effective parameter on anti-icing performance.

The verification study with optimized and analysed values can be seen in Table 4. In this study, when the error rate is being less than $10 \%$, the results can be considered as acceptable. It is understood that the optimization study is constructed very well and so the error rate is low and under acceptable condition.

Table 4. Verification with optimization and analyses results.

\begin{tabular}{cccccc}
$\boldsymbol{\alpha}$ & $\boldsymbol{L} / \boldsymbol{d}$ & $\boldsymbol{H} / \boldsymbol{d}$ & Value & $\boldsymbol{N u}$ & $\boldsymbol{\Delta P}$ \\
55.45 & 0.0 & 4.0 & Optimized & 7.7960 & $1.512 \times 10^{6}$ \\
& & & Analyse & 7.9121 & $1.554 \times 10^{6}$ \\
& & & Error (\%) & 1.49 & 2.27 \\
\hline
\end{tabular}

The correlations obtained in RSM studies both average Nusselt number and Pressure drop value can be seen from following equations:

$$
\begin{aligned}
& N u=6.556+0.05106 \alpha-0.019 \frac{L}{d}-0.2329 \frac{H}{d}-0.000329 \alpha^{2}- \\
& 0.0752 \frac{L^{2}}{d}+0.0116 \frac{H^{2}}{d}-0.00042 \alpha \frac{L}{d}+0.000874 \alpha \frac{H}{d} \\
& +0.0112 \frac{L}{d} \frac{H}{d} \\
& \Delta P=1492826+504 \alpha-2161 \frac{L}{d}-947 \frac{H}{d}-1.098 \alpha^{2} \\
& -1239 \frac{L^{2}}{d}+131 \frac{H}{d}-12.4 \alpha \frac{L}{d}-17.0 \alpha \frac{H}{d}+487 \frac{L}{d} \frac{H}{d}
\end{aligned}
$$


These equations can be utilized in range of $30 \leq \alpha \leq 150$, $1.25 \leq L / d \leq 1.25, \quad 4 \leq H / d \leq 8$ at $\dot{m}=0.004 \mathrm{~kg} / \mathrm{s}$. When these formulations can be compared to numerical results, it is obtained that the error rate both average Nusselt number and pressure drop is gotten as $1.04 \%$ and $0.097 \%$, respectively.

Table 5. Analysis of Variance $(A N O V A)$ values of average Nusselt number and pressure drop $(\triangle P)$ values in $R S M$.

a)Analysis of Variance of average Nusselt Number

\begin{tabular}{|c|c|c|c|c|c|c|c|}
\hline Source & DF & Seq SS & Contribution & Adj $S S$ & $\operatorname{Adj} M S$ & F-Value & P-Value \\
\hline Model & 9 & 4.31299 & $96.12 \%$ & 4.31299 & 0.47922 & 22 & 0 \\
\hline Linear & 3 & 0.27804 & $6.20 \%$ & 0.30041 & 0.10014 & 4.6 & 0.038 \\
\hline Jet Angle & 1 & 0.23038 & $5.13 \%$ & 0.28105 & 0.28105 & 12.9 & 0.007 \\
\hline$H / d$ & 1 & 0.04158 & $0.93 \%$ & 0.02139 & 0.02139 & 0.98 & 0.351 \\
\hline Square & 3 & 3.95121 & $88.05 \%$ & 3.20703 & 1.06901 & 49.08 & 0 \\
\hline$H / d^{*} H / d$ & 1 & 0.00238 & $0.05 \%$ & 0.00518 & 0.00518 & 0.24 & 0.639 \\
\hline 2-Way Interaction & 3 & 0.08373 & $1.87 \%$ & 0.08373 & 0.02791 & 1.28 & 0.345 \\
\hline Jet Angle*L/d & 1 & 0.03034 & $0.68 \%$ & 0.00293 & 0.00293 & 0.13 & 0.723 \\
\hline Jet Angle*H/d & 1 & 0.0501 & $1.12 \%$ & 0.03182 & 0.03182 & 1.46 & 0.261 \\
\hline$L / d * H / d$ & 1 & 0.00329 & $0.07 \%$ & 0.00329 & 0.00329 & 0.15 & 0.708 \\
\hline
\end{tabular}

\section{b)Analysis of Variance of Pressure drop}

\begin{tabular}{|c|c|c|c|c|c|c|c|}
\hline Model & 9 & 1482779994 & $96.49 \%$ & 1482779994 & 164753333 & 24.45 & 0 \\
\hline Linear & 3 & 1406358138 & $91.52 \%$ & 1367628377 & 455876126 & 67.65 & 0 \\
\hline$L / d$ & 1 & 2426401 & $0.16 \%$ & 2145073 & 2145073 & 0.32 & 0.588 \\
\hline$H / d$ & 1 & 31318083 & $2.04 \%$ & 36672228 & 36672228 & 5.44 & 0.048 \\
\hline$L / d * L / d$ & 1 & 1153476 & $0.08 \%$ & 9069517 & 9069517 & 1.35 & 0.279 \\
\hline$H / d * H / d$ & 1 & 52441 & $0.00 \%$ & 660003 & 660003 & 0.1 & 0.762 \\
\hline 2-Way Interaction & 3 & 17800792 & $1.16 \%$ & 17800792 & 5933597 & 0.88 & 0.491 \\
\hline Jet Angle*L/d & 1 & 4526256 & $0.29 \%$ & 2482043 & 2482043 & 0.37 & 0.561 \\
\hline Jet Angle*H/d & 1 & 7036989 & $0.46 \%$ & 11983336 & 11983336 & 1.78 & 0.219 \\
\hline
\end{tabular}

\section{Conclusions}

In the present study, the optimization of parameters affecting anti-icing performance on wing leading edge of aircraft is numerically studied. The following findings is found out from this study:

- Changing of $L / d$ ratio relatively affects average Nusselt number and pressure drop value and the best position of $L / d$ is obtained as $L / d=0.0$ called concentric position.

- $\quad$ Increase in $H / d$ ratio decreases average Nusselt number. The best one can be expressed as $H / d=4.0$, since it provides the highest average Nusselt number as well as pressure drop.

- The changing in $\alpha$ cause to both increase and decrease in average Nusselt number. The average Nusselt number can be increased until $\alpha=90^{\circ}$.

- The optimum $\alpha, L / d$ and $H / d$ value is obtained by $R S M$ as 55.45, 0.0, and 4.0, respectively.

- The correlations developed by RSM establish good agreement with numerical results by $1.04 \%$ and $0.097 \%$ for average Nusselt number and pressure drop, respectively. 


\section{References}

[1] L. Yi, H. Hu, C. li, Y. Zhang, S. Yang, M. Pan, Experimental investigation on enhanced flow and heat transfer performance of micro-jet impingement vapor chamber for high power electronics, Int. J. Therm. Sci. 173

(2022).

https://doi.org/10.1016/j.ijthermalsci.2021.107380.

[2] F. Selimefendigil, H.F. Öztop, Nanojet impingement cooling of an isothermal surface in a partially porous medium under the impact of an inclined magnetic field, J. Therm. Anal. Calorim. 141 (2020) 1875-1888. https://doi.org/10.1007/s10973-019-08839-9.

[3] R. Ekiciler, M.S.A. Çetinkaya, K. Arslan, Effect of shape of nanoparticle on heat transfer and entropy generation of nanofluid-jet impingement cooling, Int. J. Green Energy. 17 (2020) $555-567$. https://doi.org/10.1080/15435075.2020.1739692.

[4] A.Ü. Tepe, Numerical investigation of a novel jet hole design for staggered array jet impingement cooling on a semicircular concave surface, Int. J. Therm. Sci. 162 (2021) 106792. https://doi.org/10.1016/j.ijthermalsci.2020.106792.

[5] H.K. Pazarlığlu, R. Ekiciler, K. Arslan, Numerical Analysis of Effect of Impinging Jet on Cooling of Solar Air Heater with Longitudinal Fins, Heat Transf. Res. 52 (2021). https://doi.org/10.1615/heattransres.2021037251.

[6] E. Ayan, S. Özgen, In-Flight Mixed Phase Ice Accretion Prediction on Finite Wings with TAICE-3D, (2017) 3-10. https://doi.org/10.13009/EUCASS2017-339.

[7] O. Yirtici, K. Cengiz, S. Ozgen, I.H. Tuncer, Aerodynamic validation studies on the performance analysis of iced wind turbine blades, Comput. Fluids. 192 (2019). https://doi.org/10.1016/j.compfluid.2019.104271.

[8] T. Hikmet Karakoc, M. Baris Ozerdem, M. Ziya Sogut, C.O. Colpan, O. Altuntas, E. Açıkkalp, In-Flight Icing Simulations on Airfoils, Sustain. Aviat. Energy Environ. Issues. (2016) 279-289. https://doi.org/10.1007/978-3319-34181-1.

[9] S. Özgen, M. CanIbek, Ice accretion simulation on multielement airfoils using extended Messinger model, Heat Mass Transf. Und Stoffuebertragung. 45 (2009) 305-322. https://doi.org/10.1007/s00231-008-0430-4.

[10] T.G. Myers, Extension to the Messinger model for aircraft icing, AIAA J. 39 (2001) 211-218. https://doi.org/10.2514/2.1312.
[11] G. Mingione, V. Brandi, B. Esposito, Ice accretion prediction on multi-element airfoils, 35th Aerosp. Sci. Meet. Exhib. 35 (1997). https://doi.org/10.2514/6.1997177.

[12] T.G. Myers, J.P.F. Charpin, C.P. Thompson, Slowly accreting ice due to supercooled water impacting on acold surface, Phys. Fluids. 14 (2002) 240-256. https://doi.org/10.1063/1.1416186.

[13] T. Cebeci, H.H. Chen, N. Alemdaroglu, Fortified LEWICE with viscous effects, 28th Aerosp. Sci. Meet. 1990. 28 (1990) 564-571. https://doi.org/10.2514/6.1990-754.

[14] E. Ayan, S. Özgen, In-flight ice accretion simulation in mixed-phase conditions, Aeronaut. J. 122 (2018) 409441. https://doi.org/10.1017/aer.2017.127.

[15] L.M. Jiji, Heat convection: Second edition, Heat Convect. Second Ed. (2009) 1-543. https://doi.org/10.1007/978-3642-02971-4.

[16] N.İ.H. ALGBURI, H.K. PAZARLIOĞLU, K. ARSLAN, Effect of Pitch Ratio and Diagonal Length of Pin Fin of Heat Sink on Convective Heat Transfer for Turbulent Flow Condition, Eur. J. Sci. Technol. (2021) 643-652. https://doi.org/10.31590/ejosat.1009980.

[17] Aerospaceweb.org |Ask Us - NACA Airfoil Series, (n.d.). http://www.aerospaceweb.org/question/airfoils/q0041.sh tml (accessed November 28, 2021).

[18] B. Yang, S. Chang, H. Wu, Y. Zhao, M. Leng, Experimental and numerical investigation of heat transfer in an array of impingement jets on a concave surface, Appl. Therm. Eng. $127 \quad$ (2017) 473-483. https://doi.org/10.1016/j.applthermaleng.2017.07.190.

[19] F.R. Menter, M. Kuntz, R. Langtry, Ten Years of Industrial Experience with the SST Turbulence Model, (2003). 